Vol. 7, No. 2, 2020

https://doi.org/10.23939/eem2020.02.061

UDC 657.43:336.1

JEL Clasification Code M41, B41

\begin{abstract}
A. Balan
Odessa National Polytechnic University, Ukraine, $\mathrm{PhD}$, Associate Professor

ORCID ID: 0000-0002-2017-8813
\end{abstract}

N. Kachanova

Odessa National Polytechnic University, Ukraine, student

E. Topalova

Odessa National Polytechnic University, Ukraine, student

\title{
ACCOUNTING AND CONTROL FEATURES OF THE USING OF SPARE PARTS (PNEUMATIC TIRES, RECHARGEABLE BATTERIES) ON MOTOR TRANSPORT ENTERPRISES
}

\begin{abstract}
The modern approach to accounting of reusable spare parts of motor transport enterprise (MTE) envisages including of pneumatic tires and storage batteries in the complement of current assets. The share of costs for their maintenance in the total cost of transportation services amounts to $25 \%$, and under these conditions makes it impossible for a sufficient level of internal control (IC) to use such assets effectively. A number of scientists has investigated this issue; however, a unified approach has not been determined, which proves the pressing research problem. Hence, in times of crisis, the issue of accounting improvement, which will lead to optimization of the cost of MTE services cost, becomes especially relevant. The purpose of the research is to summarize the existing regulatory and accounting principles for the accounting of reusable spare parts, to analyze the system (IC) of the use of spare parts of MTE, to develop recommendations for their improvement and practical use. Achieving this goal requires the following tasks: to investigate the features of accounting for the use of spare parts of MTE and to determine the current methodological basis for controlling their use; to analyse tendencies of development of the transport industry of Ukraine, activity and features of accounting of tires and accumulators at MTE (PC “Avtomobilni Perevezennya "Avtoera"); based on the results of the analysis, provide recommendations for improving the organizational and methodological basis of accounting for reusable parts
\end{abstract}

with the introduction of component accounting; to develop accounting support for the process of renting pneumatic tires for PC "AP "Avtoera". The tasks are set in the work, solved using the following methods: systematization; abstract-logical analysis; empirical research (in studying the normative and theoretical basis of accounting and control of the use of pneumatic tires); classification and analytical; statistical and comparative analysis (using Microsoft Excel tools in the analysis of the financial state of PC "AP "Avtoera" to determine the main prerequisites for improving the accounting and control system for the use of pneumatic tires); testing the internal control system; dialectical and comparative (to summarize the results obtained); logical (to build the structure and summarize the results of the research). The work generalizes and analyzes the theoretical and methodological principles of accounting for pneumatic tires and batteries at motor transport enterprises, identifies alternative options for tire accounting and contradictory points that need correction, and formulates a working hypothesis. The tendencies of development of the Ukrainian transport industry, activities and features of accounting of tires and accumulators for MTE (PC “AP "Avtoera") analyzed. Improvement of organizational and methodological bases of accounting for spare parts with introduction of component accounting is proposed; accounting support for the process of renting pneumatic tires was developed, recommendations were made to make changes to the 


\section{A. Balan, N. Kachanova, E. Topalova}

accounting policy of the company, in accordance with the proposed directions for improving the organization of accounting for the use of pneumatic tires and batteries.

Key words: accounting and analytical support, spare parts, pneumatic tires, storage batteries, tire rentals, document management, internal control.

\section{Formulation of the problem.}

The complexity of accounting for spare parts of a motor transport enterprise lies in the nature of their use and recognition as current assets. On the example of the research of features of accounting of the use of pneumatic tires and batteries, the necessity of carrying out their component accounting in the composition of fixed assets of the enterprise considered.

\section{Analysis of recent research and publications.}

The mentioned problems from different points of view covered in a number of scientific works, in particular in the works of: A. V. Basiluk, O. I. Malyshkin, V. F. Maksimova, A. Khimich, K. Saiko, V. Furs, O. Kobi, V. Bilichenko, O. Akimenko, A. A. Balan, V. V. Kirsanova, N. M. Selivanova and others. At the same time, the number of accounting and control aspects of the problem remains unresolved.

\section{The purpose of scientific research}

The purpose of the research is to systematize and adjust the methodological bases for the accounting of reusable spare parts, to analyze the system of internal control of the use of spare parts at motor transport enterprises, to develop recommendations for their improvement and practical use.

Separate provisions and results of the study were presented in the following scientific works: $[1,2,3]$.

\section{Explanation of the main material of the research}

Motor transport enterprises occupy a significant share in the national economy sector, they ensure the continuous functioning of most industries, improve the quality of life of the population and its mobility, promote the development of relations in the field of foreign economic activity. Road transport in the domestic market is the most advanced, as according to the State Statistics Service of Ukraine [4] $73.37 \%$ of cargoes are carried by freight motor transport (Fig. 1, Appendix A), in addition, the volume of transportation increased, for the period 2016-2018 they increased by $11.04 \%$ (Tab.1, Appendix B).

Pneumatic tires and batteries required for the current and major overhaul of transport at the MTE are included in the item of expenditure for material and service costs used in production. This item is the most significant in the structure of expenses and makes $81.6 \%$ (Fig. 2), which proves the expediency of optimization of this item of expenses.

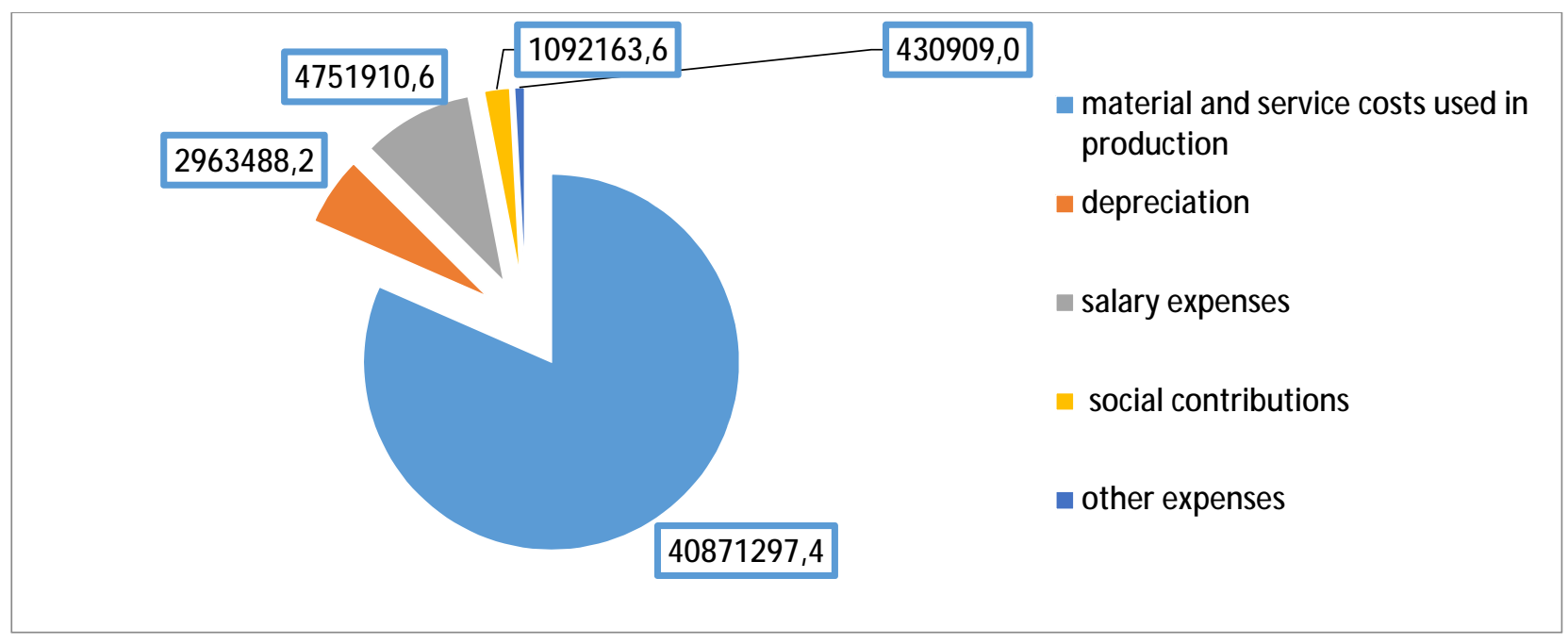

Fig. 2. Cost structure of enterprises (thousand UAH) operating in NACE 49.41 Freight road transport in 2018 Source: compiled by the authors on the materials [4]. 
Spare parts at a motor transport enterprise (MTE) are one of the most important components of an assets and are usually used for internal needs: repair, improvement and modernization of machines and equipment that are on the balance of the company. Spare parts are related to the costs of the enterprise and affect the results of its business activities, and, accordingly, require the most exact accounting and control.

The specifics of this category are the so-called reusable spare parts (pneumatic tires and batteries), the accounting of which differs significantly under national and international law. The authors will consider the possible variants of their accounting, highlight the advantages and disadvantages of each one. The analysis of the legal framework and scientific database in the direction of spare parts accounting and control is presented in Tab. 2-3 (Appendix C-D).

The background of the research is first of all the contradiction of the reusable spare parts of the conditions for attribution of the object to current assets: the operation period of pneumatic tires and batteries more than one year; the value of these objects exceeds the value criterion for attribution of the tangible assets to the "property, plant and equipment (PPE)" noticed in article 14 of the Tax Code of Ukraine [17]; require periodic repair and regain.

Table 4

Price overview of actual truck tire models as of early $\mathbf{2 0 2 0}$

\begin{tabular}{|c|c|c|c|}
\hline \multirow{2}{*}{ Producer } & \multicolumn{3}{|c|}{ Price, UAH } \\
\cline { 2 - 4 } & $295 / 60, \mathrm{R} 22,5^{*}$ & $315 / 70, \mathrm{R} 22,5$ & $385 / 65, \mathrm{R} 22,5$ \\
\hline \multicolumn{4}{|c|}{ INFOSHINA (seller) } \\
\hline MATADOR & 8132 & 8025 & 8239 \\
\hline BRIDGESTONE & 12500 & 11055 & 10786 \\
\hline AELUS & 6050 & 7374 & 8987 \\
\hline GOODYEAR & 8011 & 12200 & 9536 \\
\hline MATADOR & SHIPSHINA (seller) & 13308 \\
\hline BRIDGESTONE & 9591 & 9426 & 9500 \\
\hline AELUS & 8658 & 14821 & 13099 \\
\hline GOODYEAR & 6896 & 8895 & 14882 \\
\hline
\end{tabular}

Source: compiled by the authors on the materials [18-19].

Notes: *-width, profile and diameter of the pneumatic tire.

The high cost of pneumatic tires and batteries in most cases exceeds the value criterion of attribution of the object to fixed assets, specified in the Tax Code of Ukraine in the amount of $6000 \mathrm{UAH}$. The high cost of new pneumatic tires also indicates the feasibility of optimizing the costs of purchasing and operating them. One of the solutions in this situation is to rent pneumatic tires. Table 4 provides an overview of the pricing policies of pneumatic tire manufacturers and sellers in the Ukrainian market as of early 2020.

There are two ways of accounting for pneumatic tires and batteries on a sub-account 207 "Spare Parts". The first way is to account objects at their historical cost until writing off as a result of unsuitability. The using of this method requires the opening of additional sub-accounts (but the 


\section{A. Balan, N. Kachanova, E. Topalova}

analytical accounting of tires and batteries can be conducted on various signs (Fig. 3, Appendix E):

- 207.1 "Pneumatic tires";

- 207.11 "Pneumatic tires in stock";

- 207.12 "Pneumatic tires in operation";

- 207.13 "Pneumatic tires under repair (restoration)";

- 207.14 "Restored pneumatic tires in stock";

- 207.15 "Restored pneumatic tires in operation";

- 207.2 "Storage batteries";

- 207.21 "Storage batteries in stock";

- 207.22 "Storage batteries in operation";

- 207.23 "Storage batteries transferred for repair (restoration)".
An example of the application of the proposed accounts for the registration of business transactions is given in Tab. 5 .

This method is not perfect because valuing car tires and batteries in use at initial cost is an overestimation of the real value of the assets of the enterprise, because the process of operation is accompanied by loss of cost wear.

The second way is to write off the cost of commissioning. This method is more imperfect, since the commissioning of pneumatic tires and batteries is accompanied by the write-off of their cost (by types 23, 91, 92, 93, 94 sub-accounts), which makes it impossible to keep track of accounting accounts [20].

Table 5

Application of additional sub-accounts for tire and battery accounting [11-16]

\begin{tabular}{|c|c|c|c|}
\hline Contents of the business operation & Debit & Credit & Document \\
\hline Received at the stock purchased tires (batteries) & $\begin{array}{l}207.11 \\
207.21\end{array}$ & 631 & $\begin{array}{l}\text { Waybill, the card of inventory } \\
\text { accounting }\end{array}$ \\
\hline Calculated VAT tax credit & 641 & 631 & Tax waybill \\
\hline Purchased tires (batteries) installed for the car & $\begin{array}{l}207.12 \\
207.22\end{array}$ & $\begin{array}{l}207.11 \\
207.21\end{array}$ & $\begin{array}{l}\text { Requisition slip, Tire (batteries) working } \\
\text { accounting card }\end{array}$ \\
\hline Registered removed from the car tires (batteries) & $\begin{array}{l}207.11 \\
207.21\end{array}$ & $\begin{array}{l}207.12 \\
207.22\end{array}$ & $\begin{array}{l}\text { Requisition slip, the card of inventory } \\
\text { accounting, Tire (batteries) working } \\
\text { accounting card }\end{array}$ \\
\hline Damaged tires (batteries) transferred for repair & $\begin{array}{l}207.13 \\
207.23\end{array}$ & $\begin{array}{l}207.11 \\
207.21\end{array}$ & $\begin{array}{l}\text { Requisition slip, the card of inventory } \\
\text { accounting, Tire (batteries) working } \\
\text { accounting card }\end{array}$ \\
\hline $\begin{array}{l}\text { Repair of the damaged tires (batteries) } \\
\text { completed }\end{array}$ & $\begin{array}{l}23 \\
91\end{array}$ & 631 & Work completion statement \\
\hline $\begin{array}{l}\text { Registered tires (batteries) at the stock after } \\
\text { repair }\end{array}$ & $\begin{array}{l}207.11 \\
207.21\end{array}$ & $\begin{array}{l}207.13 \\
207.23\end{array}$ & Waybill, the card of inventory \\
\hline Tires (batteries) installed for the car & $\begin{array}{l}207.12 \\
207.22\end{array}$ & $\begin{array}{l}207.11 \\
207.21\end{array}$ & accounting card \\
\hline
\end{tabular}

It is inappropriate to use this method because of a fundamental violation of paragraph 23 of NSAU 9 "Inventories", whereby only the value of low-value and high-wear items to which the pneumatic tires and batteries are not included can be excluded from the assets. The algorithm of using the second method on the example of the use of pneumatic tires is presented in Fig. 4.

Accounting for reusable spare parts as an item of property, plant and equipment in accordance with IASB 16 "Property, Plant and Equipment" is possible provided that the entity expects to use the spare part for more than one period and if it is used only in connection with the object of the PPE [21].

Basiluk A. V. and Malyshkin O. I. [22] investigated: primary accounting for the purchase and writing-off of spare parts; display of results of liquidation of spare parts; tire accounting; displaying transactions in reporting forms and tax accounting for spare parts. The authors look at typical MTE situations and suggest alternative methods for controlling tire costs. 


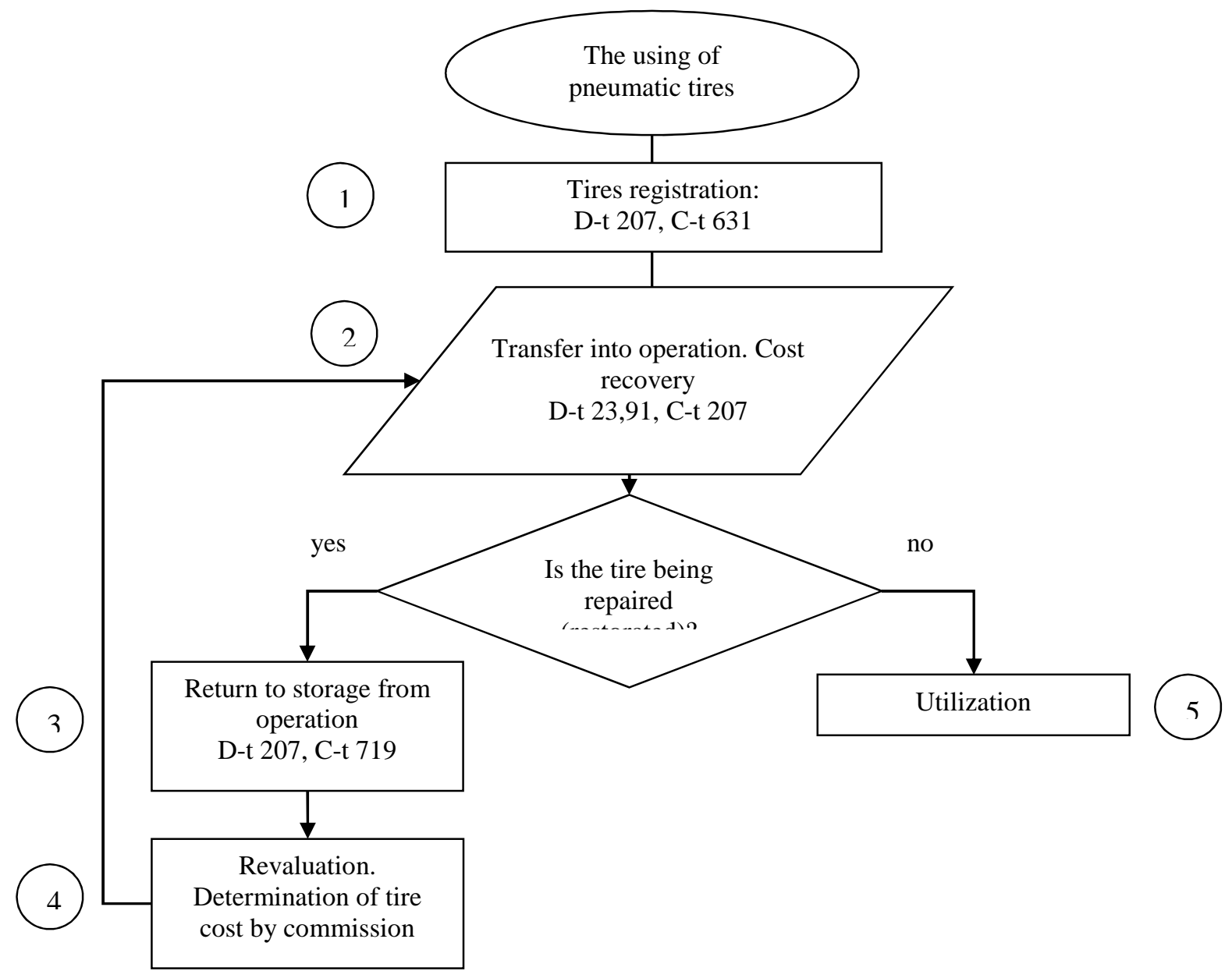

Fig. 4. Algorithm for the implementation of the first method of accounting for pneumatic tires with write-off for the cost of commissioning

Notes: Documents accompanying the tire use process:: 1 - waybill; 2 - requisition still, the act of writing-off; 3 -warehouse accounting card; 4 - protocol of the commission decision; 5 - tire recycling agreement.

Source: compiled by the authors on the materials [11, 14, 20].

The first alternative of accounting involves the recording of tires and batteries not on 207 subaccounts, but on 112 as low-value non-current tangible assets, the second option consists in the allocation to a sub-account 23 of a separate item for repair and replacement of tires. The authors also describe the variant used under irrelevant accounting rules, accounting for spare parts for sub-account 22 - Low value items. These accounting optimization methods allow tracking the cost of new tires and the cost of recovery.

One of the features of accounting for spare parts is the existence of differences in accounting and tax accounting. In accounting, the cost of spare parts used in the repair of the vehicle is written off against the costs of the enterprise. In tax accounting it is determined that if the cost of repair does not exceed $10 \%$, in order to eliminate the double attribution of the cost of spare parts to the gross costs (when purchasing and writing off production costs), spare parts are involved in the calculation of the increase or decrease in the book value of inventories.

If the amount of repairs exceeds $10 \%$, then the cost of spare parts used in the repair should be excluded from inventory balances at the beginning of the reporting period, this accounting scheme is shown in Fig. 5 [23].

The analysis of contradictory provisions of regulatory acts, violation of accounting principles by existing methodological principles, shortcomings 


\section{A. Balan, N. Kachanova, E. Topalova}

and advantages of possible variants of accounting of pneumatic tires and batteries in accounting accounts (Tab. 6), made it possible to conclude that

accounting of these objects in the composition of irregularities the best option for creating the right accounting security.

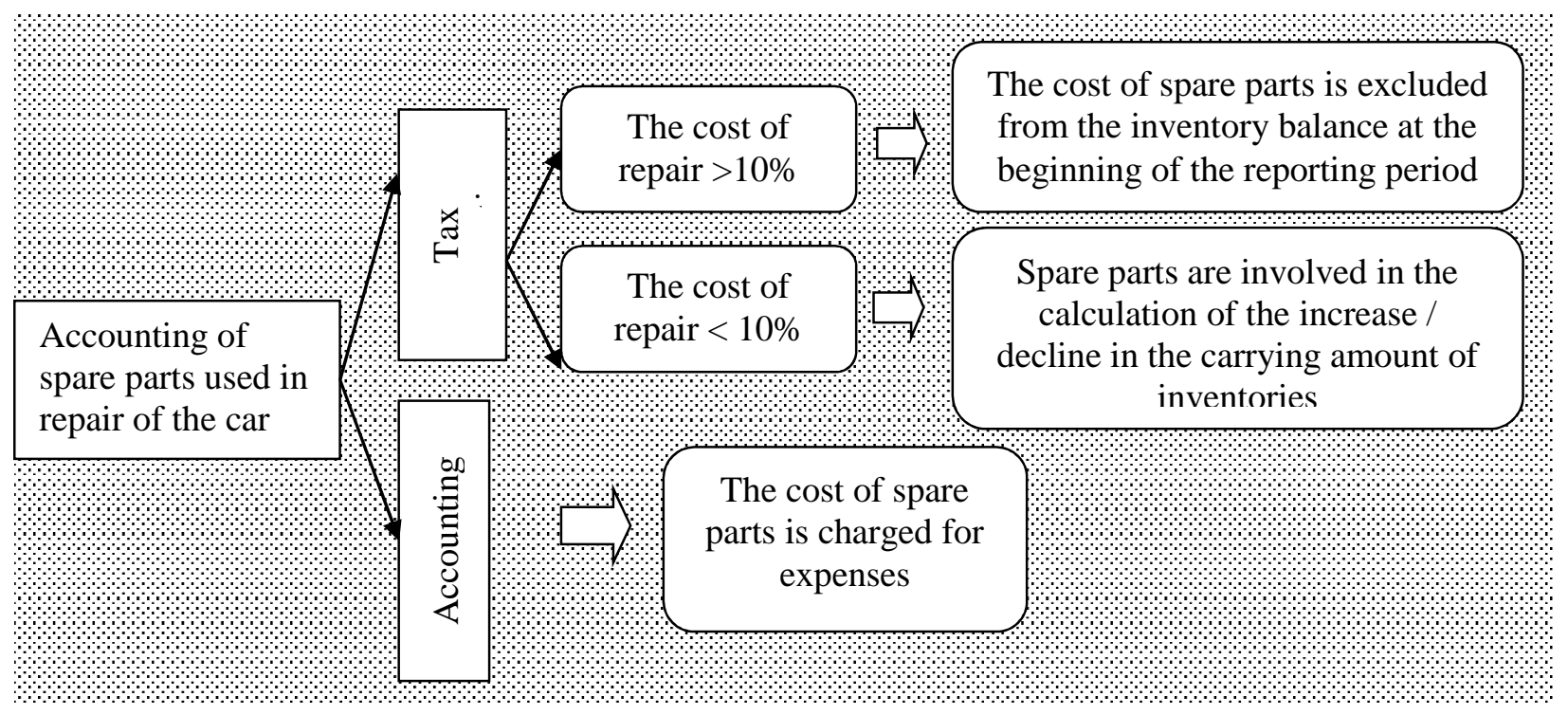

Fig. 5. Differences in accounting and tax accounting when used in the repair of a vehicle spare parts

Source: compiled by the authors on the materials [23].

Systematic list of possible options for the accounting of reusable spare parts (for example pneumatic tires) in accounting accounts for MTE

\begin{tabular}{|c|c|c|c|}
\hline \multicolumn{2}{|r|}{ Variant } & ADVANTAGES & DISADVANTAGES \\
\hline \multirow{2}{*}{ 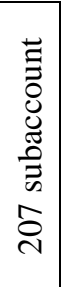 } & $\begin{array}{l}\text { At historical } \\
\text { cost }\end{array}$ & $\begin{array}{l}\text { Ability to track in-service tires on sub- } \\
\text { accounts }\end{array}$ & $\begin{array}{l}\text { Overstatement of the real value of the } \\
\text { enterprise assets contradicts the } \\
\text { implementation of the rent tires process }\end{array}$ \\
\hline & $\begin{array}{l}\text { Write-offs on } \\
\text { costs }\end{array}$ & Governed by NSAU & $\begin{array}{l}\text { Impossible to track tires value after } \\
\text { implementation in the operation; violation of } \\
\text { point } 23 \text { NSAU } 9 \text { "Stocks" }\end{array}$ \\
\hline \multicolumn{2}{|c|}{$\begin{array}{l}23 / \\
\text { "Tire repair and } \\
\text { replacement" }\end{array}$} & $\begin{array}{l}\text { Allows you to write-off the cost of a new } \\
\text { tire when installed on the vehicle and the } \\
\text { cost of repair }\end{array}$ & $\begin{array}{l}\text { The account reflects not only the costs } \\
\text { written-off but also the costs remaining in the } \\
\text { warehouse as retreaded tires. }\end{array}$ \\
\hline \multicolumn{2}{|c|}{$\begin{array}{l}105 \\
\text { "Vehicles" }\end{array}$} & $\begin{array}{l}\text { It is governed by IAS 16; it is appropriate } \\
\text { because of the cost criterion and the long } \\
\text { duration of tire operation; option of } \\
\text { component accounting; Tire rental possible }\end{array}$ & $\begin{array}{l}\text { According to NSAU } 7 \text { tires are not PPE } \\
\text { because they cannot perform separate } \\
\text { functions separately from the vehicles; only } \\
\text { the first tire set and the "spare part in the car" } \\
\text { are considered by the PPE }\end{array}$ \\
\hline \multicolumn{2}{|c|}{$\begin{array}{l}112 \\
\text { Non-current } \\
\text { tangible assets of } \\
\text { low cost }\end{array}$} & $\begin{array}{l}\text { Allows you to track the cost of new tires } \\
\text { that have been recovered, the cost of } \\
\text { rebuilding them through the surplus account } \\
\text { of the "Used Tires" }\end{array}$ & $\begin{array}{l}\text { Assigning the amount of tire retreading to the } \\
\text { first event will increase the gross cost, while } \\
\text { their cost does not fit into the "low value" } \\
\text { category }\end{array}$ \\
\hline \multicolumn{2}{|c|}{$\begin{array}{l}22 \\
\text { Low-value items }\end{array}$} & $\begin{array}{l}\text { Makes possible the application of the } \\
\text { method of accounting of tires, writing off } \\
\text { the costs at commissioning, does not violate } \\
\text { point } 23 \text { NSAU } 9 \text { "Stocks" }\end{array}$ & $\begin{array}{l}\text { The cost of the tires is high, so they cannot be } \\
\text { considered inferior and have a lifetime of } \\
\text { more than a year }\end{array}$ \\
\hline
\end{tabular}


In view of the foregoing, the working hypothesis of the research requiring analytical confirmation and methodological justification is as follows: adjusting the methodological bases of accounting for pneumatic tires and batteries will optimize the cost of purchasing reusable spare parts, track their cost in accounting accounts at each stage of operation (repair, restoration, writeoff), to avoid violations of accounting standards and related sanctions; to harmonize accounting and tax accounting of spare parts as much as possible; implement the process of renting pneumatic tires in accordance with current legislation.

In order to confirm the working hypothesis, the experience of a typical motor transport enterprise, selected because of the analysis of accounting policies of enterprises operating under the NACE Freight Motor Transport, was analyzed. Private Company "AP "AVTOERA" provides transportation services in particular of grain crops by truck. In the course of the analysis of the financial statements of the Private Company "AP "AVTOERA", a number of deviations were detected, signaling the pre-crisis state of the enterprise (tab. 7, Appendix F).

The accounting of pneumatic tires and batteries directly at the PC "AP "AVTOERA", as well as at most MTEs, is organized according to the traditional classification and requirements of the NSAU 9 and is accompanied by a number of imperfections. Accordingly, the write-off process is performed according to the same algorithm for all spare parts, and is executed by conducting the business transaction with the following correspondence of accounts: on the debit of the sub-account of expenses of the enterprise 91 "General expenses", on the credit of the subaccount of 207 "Spare parts". In this case, the write-off of pneumatic tires and batteries thus requires that, upon returning to storage, the following economic operation be made: on the debit of sub-account 207 "Spare Parts", and on the credit of sub-account of 719 "Other operating income".

Receipts of reusable spare parts in monetary terms are given in Table 8. Thus, in 2016, the company purchased only pneumatic tires in the amount of 401.81 thousand UAH. In 2017, the proportion of the amount of disposable spare parts was $59.12 \%$, and reusable $-40.88 \%$, of which tires $-38.79 \%$, batteries $-2.09 \%$. In 2018 , the share of disposable spare parts increased by $7.42 \%$ and amounted to $66.54 \%$ and reusable to $33.46 \%$. The share of tires decreased by $8.59 \%$ and amounted to $30.20 \%$, and batteries $-3.26 \%$.

Table 8

Share of types of spare parts (in monetary terms) in the total amount of spare parts receipts at PC "AP "AVTOERA"

\begin{tabular}{|l|c|c|c|c|c|c|}
\hline \multirow{2}{*}{ Kind of spare parts } & \multicolumn{2}{|c|}{2016} & \multicolumn{2}{c|}{2017} & \multicolumn{2}{c|}{2018} \\
\cline { 2 - 7 } & $\begin{array}{c}\text { thousand } \\
\text { UAH }\end{array}$ & $\%$ & $\begin{array}{c}\text { thousand } \\
\text { UAH }\end{array}$ & $\%$ & thousand UAH & $\%$ \\
\hline Disposable & - & - & 1247.87 & 59.12 & 3675.30 & 66.54 \\
\hline Reusable & 401.81 & 100.00 & 862.86 & 40.88 & 1848.20 & 33.46 \\
\hline -tires & 401.81 & 100.00 & 818.74 & 38.79 & 1668.04 & 30.20 \\
\hline - batteries & - & - & 44.12 & 2.09 & 180.16 & 3.26 \\
\hline Total & 401.81 & 100.00 & 2110.73 & 100.00 & 5523.50 & 100.00 \\
\hline
\end{tabular}

The analysis of the internal control system in the aspect of spare parts is made in Tab. 9 (Appendix G) in the form of testing to determine the existence of accounting, document management and spare part control issues.

The conducted testing has revealed that the enterprise is not properly carrying out the process of writing-off of reusable spare parts; there is no necessary documentation for accounting of pneumatic tires and batteries, which can be used to track the condition, location and level of wear of spare parts. In addition, the company does not enter additional sub-accounts to 207 accounts, does not take into account the legally stipulated and actual 


\section{A. Balan, N. Kachanova, E. Topalova}

rates of tire operation when they are written off, rented tires are not tracked in accounting accounts. The presence of such problems indicates the need to improve the system of internal control of the use of spare parts and eliminate the shortcomings of the organization of accounting for pneumatic tires and batteries, rental of tires.

Improvement of the methodological foundations of the process of decommissioning of reusable spare parts is to develop a detailed algorithm, at each of which stages it will be possible to track all the necessary information regarding the condition of pneumatic tires and batteries in the enterprise.

NSAU 7 "Property, Plant and Equipment" provides for a component account of property, plant and equipment, according to which the unit of account is also a separate complex of structurally connected objects of the same or different purpose [24]. This definition can be attributed to the car as the object of property, plant and equipment that only in combination with pneumatic tires, batteries and other components can fulfill its purpose in the enterprise - the provision of freight services. It should be noted that if the complex components have a different useful life, then in accordance with Methodological Recommendations № 561 [25], the company has the right to independently consider the complex as a single object of PPE, or each of the components separately.

The complexity of determining the original cost of each individual component relating to the first and spare sets of pneumatic tires and the battery is solved by clause 9 of NSAU 7 "Property, Plant and Equipment" [24], which states that the initial value formed by the total is proportionally proportional to the value of the component in the total fair value of the item.

Therefore, it is proposed to keep pneumatic tires and batteries in the sub-account 105 "Vehicles" using the component accounting of property, plant and equipment, and it is proposed to open additional sub-accounts indicated in fig. 6 .

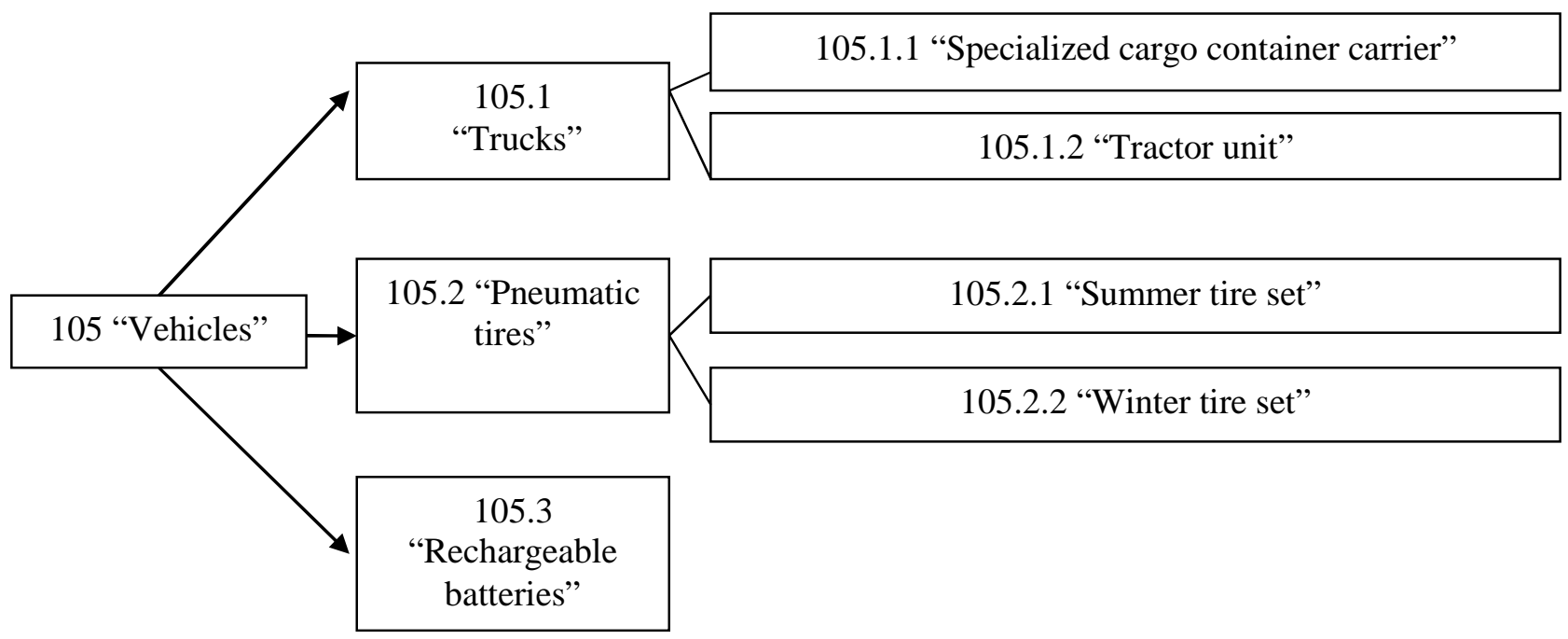

Fig. 6. Development of additional sub-accounts for account 105 "Vehicles" for component accounting of trucks

Using additional sub-accounts allows tracking the seasonality of a pneumatic tire kit from the stage of purchase to disposal or completing disposal of the tire. Batteries do not have additional sub-accounts, as they are not subject to seasonal replacement, but can only be decommissioned for repair, recharging and other necessary processes that can be tracked by internal documents.

Tire and battery accounting for property, plant and equipment requires depreciation, and it is proposed to calculate depreciation by the production method most appropriate for motor vehicles. The production method of depreciation involves the calculation of the production rate of depreciation.

For pneumatic tires, the calculation of the production rate is proposed to be carried out using the data of Performance norm № 488 [7], in which it is possible to find individual data for the various tire models and vehicles with which they operate. 
On PC "AP «AVTOERA»", tires are purchased with the following characteristics: size 315/80 R22,5, 156/150 M, M729, manufacturer - Bridgestone. According to these indicators, the tire operating time is 225 thousand $\mathrm{km}$, which is typical under normal tire operating conditions. The calculation of the actual norms of the average tire pneumatic tire resource is made to predict the need for the tire's business activity; to determine the reasons for writing off tires; predicting the volume of tire utilization. It is proposed to calculate the actual tire operating rates adjusted by coefficients, the adjustment should not exceed $25 \%$. The values of the correction coefficients typical for the PC "AP «AVTOERA»" and an example of calculation are given in Tab. 10.
The value of the adjusted value of the life of pneumatic tires should not exceed $25 \%$ in total, in our case the normalized value was adjusted by $17.44 \%$, which is within the normal range.

The trucks at the PC "AP «AVTOERA»" make about 80-90 thousand $\mathrm{km}$ per year, which means that the tires serve about 2.6 years at the enterprise. For rechargeable batteries according to Rules № 795 [9], the useful life is approximately 2.5-2.7 years. Therefore, accounting for depreciation by production method for pneumatic tires and batteries as property, plant and equipment is similar and is shown in Table 11, if the original cost of the purchased tire is $8500 \mathrm{UAH}$ and liquidation $400 \mathrm{UAH}$.

Table 10

Values of correction coefficients and example of calculation of actual value of operating standards

\begin{tabular}{|l|c|}
\hline \multicolumn{1}{|c|}{ The name of the indicator } & Value \\
\hline$K_{1}-$ correction factor according to the climatic conditions of operation & 0.98 \\
\hline$K_{2}-$ correction factor according to the intensity of operation of the pneumatic tires & 0.9 \\
\hline$K_{3}-$ correction factor according to the duration of the tire life & 1.04 \\
\hline$K_{4}-$ adjustment factor for load capacity utilization & 0.98 \\
\hline $\begin{array}{l}K_{5}-\text { correction factor pneumatic tires for cars, trucks, Heavy and long vehicles that are constantly } \\
\text { used with trailers }\end{array}$ & 0.9 \\
\hline$K_{6}-$ correction factor for the ratio of city-to-city mileage outside the city & 1.04 \\
\hline Normative value of the average tire tire life (thousand km) & 225.00 \\
\hline $\begin{array}{l}\text { Actual value of the pneumatic tire average life (thousand } \mathrm{km}) \\
(225,00 * 0,98 * 0,9 * 1,04 * 0,98 * 0,9 * 1,04)\end{array}$ & 185.75 \\
\hline
\end{tabular}

Table 11

Example of depreciation of pneumatic tires by production method for PC “AP «AVTOERA»”

\begin{tabular}{|l|c|c|c|}
\hline \multicolumn{1}{|c|}{ Contents of the business operation } & D-t & K-t & Sum \\
\hline Production rate calculation & $(8500-400) / 185750=0.044$ UAH/km \\
\hline Depreciation on a month if the actual output is 7100 km & \multicolumn{2}{|c|}{$0.036^{*} 7100=312.40 \mathrm{UAH}$} \\
\hline Depreciation is calculated on a monthly basis & 91 & 131 & 312.40 \\
\hline
\end{tabular}

Due to the calculations given in Tab. 10-11, the accounting and analytical information obtained as a result of them will be much higher and as much as possible adjusted and adapted to the specific conditions of operation of pneumatic tires at PC "AP «AVTOERA»".

Considering that, pneumatic tires and batteries may be under repair, it is proposed to suspend the depreciation of pneumatic tires and batteries at the time of its implementation. Due to this stop, it will be possible to track exactly which set is in operation and on which it is depreciated, and which is withdrawn (for the reasons specified in the card for accounting of working hours of the tire) and suspended depreciation. It is suggested that the decommissioning of tires and accumulators be made by the orders of the governing bodies of the enterprise and the corresponding entry in the individual cards of working hours. And commissioning by the act of commissioning after repair (form 
№ OZ-2). When accounting for pneumatic tires and batteries as a part of PPE, the write-off process follows the standard scheme for property, plant and equipment without violating accounting principles. When transferring tires and batteries for recycling, a check is made similar to the normal sale of materials, is transferred to the composition of PPE held for sale at the expense of 286.

It is important that the process of renting tires, which has not yet been described in the national theoretical and regulatory literature, is impossible in accounting for tires in the stock, because according to NSAU 14 "Rent" [26] rent is an agreement under which the tenant acquires the rights to use the PPE for a fee within the period agreed with the landlord. The key in this definition is the statement "use of a non-current asset", i.e. only the rent of such assets is allowed, which again confirms the expediency of accounting for pneumatic tires in the property, plant and equipment. Among the advantages of the process of renting tires over their usual purchase are the following:

- payment is made only for actual mileage;

- all moments regarding the operation of the tire service are borne by the firm landlord (which is stipulated in the terms of the tire rent agreement);

- as a result, the tenant optimizes the mileage and cost of transportation (the cost of the mileage is offered by the lessor is lower than that calculated at the enterprise);

- no need to take responsibility for the timely disposal of used pneumatic tires;

- the working capital intended for the purchase of tires is released.

Calculating the cost of your own kilometer of tire mileage and periodically comparing it with the one proposed in the contract will allow you to determine a better way to get tires. The registration of business operations for the rental of tires is given in Tab. 12.

Table 12

\section{Example of typical business operations for the rental of tires}

\begin{tabular}{|c|c|c|c|c|}
\hline Contents of the business operation & D-t & K-t & Document \\
\hline Received pneumatic tires for rent & \multicolumn{2}{|c|}{01} & $\begin{array}{c}\text { The act of acceptance-transfer and installation of } \\
\text { the object of rent }\end{array}$ \\
\hline The rent for the tires received is charged & 91 & 631 & Vehicle mileage calculation \\
\hline Calculated VAT tax credit & 641 & 631 & Tax waybill \\
\hline Rent paid & 631 & 311 & Voucher \\
\hline $\begin{array}{c}\text { Tires returned for the depreciated value } \\
\text { under the contract }\end{array}$ & \multicolumn{2}{|c|}{01} & $\begin{array}{c}\text { The act of removal and acceptance of the leased } \\
\text { property }\end{array}$ \\
\hline
\end{tabular}

Rent of non-current assets is, in turn, possible and according to Instruction № 291 [27] it is recommended to account for rented non-current assets under the off-balance-sheet account 01 "Rented non-current assets" at the carrying amount stipulated in the tire rent agreement. The list of proposed developments and changes in the organization of accounting for the use of pneumatic tires and batteries at PC "AP «AVTOERA»" will make it necessary to revise the accounting policies of the company. Therefore, recommendations for changes in accounting policies are summarized in Tab. 13 (Appendix H).
Accounting for pneumatic tires and batteries as a part of property, plant and equipment causes a change in the documentation of accounting and control over the movement of these objects in the course of business activities of the enterprise. The documentary provision for accounting for PPE does not fully meet the necessary requirements for controlling the use of tires and batteries.

The deed of conveyance (internal movement) of PPE (form № OZ-1), which is recommended for registration of receipts to the company of tires and batteries, does not require improvements, because it contains all the necessary information about the object. 
Taking into account that the company did not organize the documentary accounting of tires and accumulators in the tire accounting (running) Card of the pneumatic tire and in the performance accounting and battery tracking Card, it is proposed to introduce obligatory keeping of the card data for each tire unit and accumulator objects, number and results of repair work, seasonal replacement.

Card data metrics should be consistent with the depreciation charge to record the charge suspension. Each record of this card must have a reason, justified by the availability of the relevant document, for example, the basis for the decommissioning of the tire for repair is the order of the governing bodies of the enterprise to carry out the repair of the object. These cards are an alternative to inventory cards for accounting for property, plant and equipment, and are more appropriate for use with regard to pneumatic tires and batteries because of their maximum consideration of the features and specific characteristics of these objects. Examples of filling the pneumatic tire accounting (running) Card are given in Appendix I, and the performance accounting and battery tracking Card are given in Appendix J for PC "AP «AVTOERA»".

The decommissioning of pneumatic tires and batteries for the purpose of repair work and seasonal replacement must be accompanied by appropriate instructions from the governing bodies of the enterprise. In order to increase the efficiency and improve the organization of documentary control at the enterprise, during the research, the recommended forms of orders of the governing bodies were developed and listed in Appendix K.

The seasonal tire change order is only applicable for summer tire and winter tire changes, and the fixed asset repair order applies for decommissioning for both battery and pneumatic tires.

Taking into account the necessary specific documents that were developed to ensure a high level of accounting and analytical information of the processes of accounting and control of the use of pneumatic tires and batteries at the enterprise, a new cycle of document flow of objects was developed at PC "AP «AVTOERA»". The document cycle of document flow is shown in Fig. 7.

Above is an improved and adapted document flow that will provide accounting and analytical information of the required level regarding the use of tires and batteries purchased by the company. To ensure a similar level of accounting and analytical information regarding the status of leased pneumatic tires, it is necessary to develop an appropriate document flow.

The installation of rented pneumatic tires on the vehicles of the lessee is formalized by the Deed of conveyance and installation of the rent object, which has an arbitrary form of assembly, but must contain a mandatory list of details, the presence of which is regulated by the Regulation on Documentary Support of Accounting Entries No. 88 [28 ].

The removal from the vehicles of the lessee and the return of the pneumatic tires to the lessor is formalized by a similar Act of removal and conveyance of the leased property. In addition to the specified parameters in the deed of conveyance and installation of the object of rent, the act of removal assumes the existence of additional parameters: vehicle type (main or trailer); odometer performance.

Pneumatic tire rental charges are calculated in accordance with the vehicle mileage calculations set out in a separate document, the form of which is provided by the lessor at the end of the month. This document summarizes the indicators of the deed of conveyance of the rent object and the act of removal and conveyance of the object of rent and sums up the total amount for the month. An example of a recommended form of calculation of mileage of vehicles is given in Tab. 14 .

In order to make strategic management decisions regarding the feasibility of renting pneumatic tires compared to the purchase, it is necessary to calculate the actual operating time of their own tires, and the cost rate of thousands of $\mathrm{km}$. mileage. Having considered and improved the necessary forms of accounting for rented tires, we will demonstrate the developed cycle of document flow of the process of renting tires (Fig. 8).

Developing document form enhancements and creating document flow cycles allow us to 


\section{A. Balan, N. Kachanova, E. Topalova}

move to the next stage of improving the internal control system for the use of spare parts and pneumatic tires and batteries in the property, plant and equipment of the enterprise.

Similar internal control tasks are also performed with respect to the property, plant and equipment that are considered to account for pneumatic tires and batteries. So, in Fig. 9 shows a step-by-step algorithm for controlling the operation of tires and batteries in the property, plant and equipment.

Compliance with a step-by-step plan to control the operation of tires and batteries at the enterprise will avoid the most common problems that occur with an inefficient internal control system: malpractice, failure to perform or poor performance of duties, misjudgment of operations of property, plant and equipment and from the point of view of cost effectiveness .

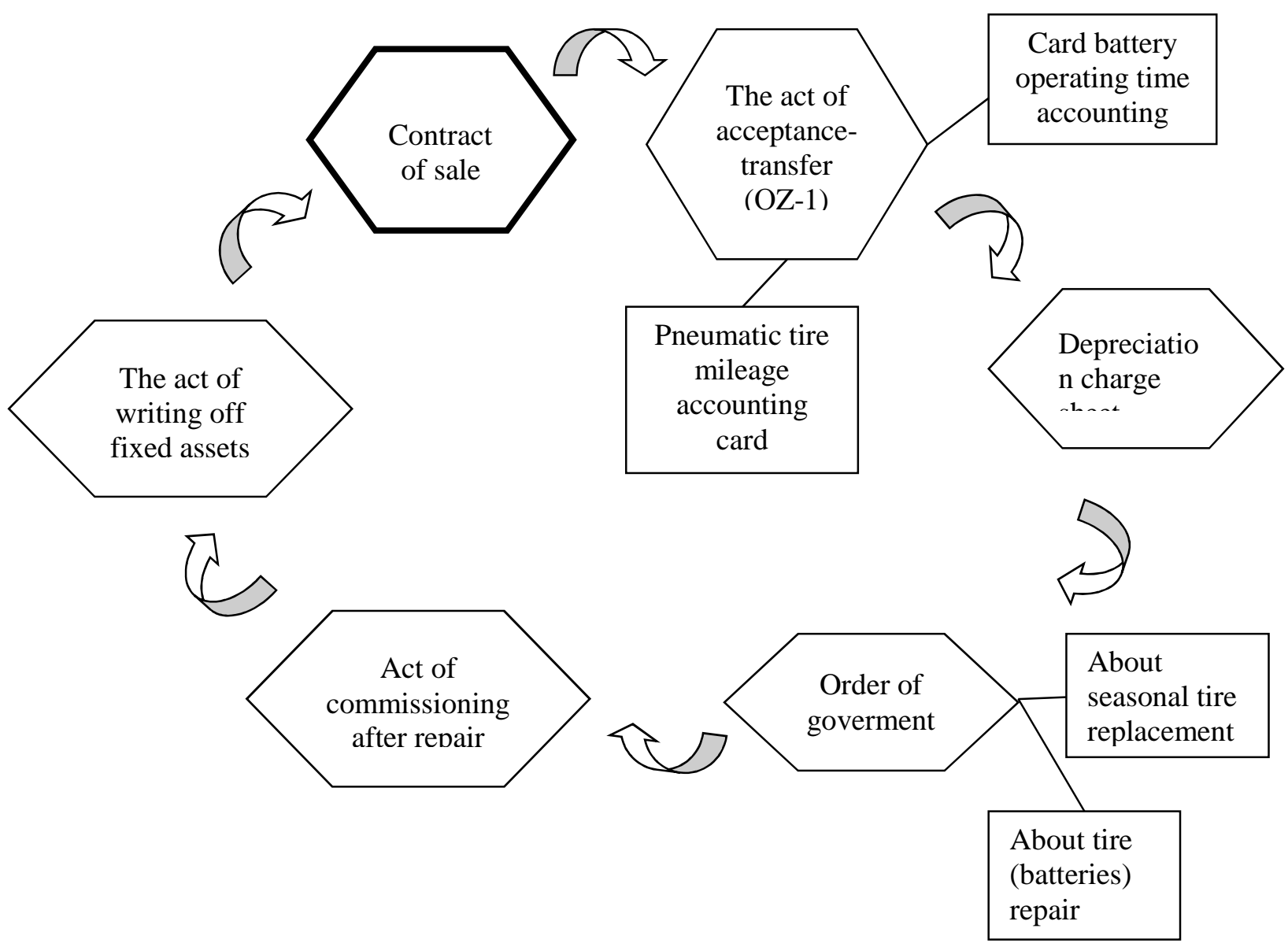

Fig. 7. Recommended document flow for accounting and control of the use of pneumatic tires and batteries in the property, plant and equipment

Table 14

Recommended form of calculation of vehicle mileage for PC "AP «AVTOERA»"

\begin{tabular}{|c|c|c|c|c|c|c|c|c|}
\hline \multirow{2}{*}{$\begin{array}{l}\text { Vehicle } \\
\text { registration } \\
\text { numbers }\end{array}$} & \multirow{2}{*}{$\begin{array}{l}\text { Vehicle type } \\
\text { (destination) }\end{array}$} & \multicolumn{3}{|c|}{ Odometer reading, km } & \multicolumn{2}{|c|}{$\begin{array}{l}\text { Mileage for the period, } \\
\mathrm{km}\end{array}$} & \multirow{2}{*}{$\begin{array}{l}\text { Rate, } \\
\text { UAH }\end{array}$} & \multirow{2}{*}{$\begin{array}{l}\text { Amount, } \\
\text { UAH }\end{array}$} \\
\hline & & $\begin{array}{l}\text { At the } \\
\text { beginning of } \\
\text { the rent }\end{array}$ & $\begin{array}{l}\text { at the } \\
\text { b.p. }\end{array}$ & $\begin{array}{l}\text { at the } \\
\text { e.p. }\end{array}$ & $\begin{array}{l}\text { Rent } \\
\text { (total) }\end{array}$ & Reporting & & \\
\hline VN0851ET & Main & 979264 & 1051817 & 1064700 & 85436 & 12883 & 613.24 & 7900.4 \\
\hline VN4861XM & Trailer hitch & 979264 & 1051817 & 1064700 & 85436 & 12883 & 635.96 & 8193.0 \\
\hline
\end{tabular}


Accounting and control features of the using of spare parts (pneumatic tires, rechargeable batteries)...

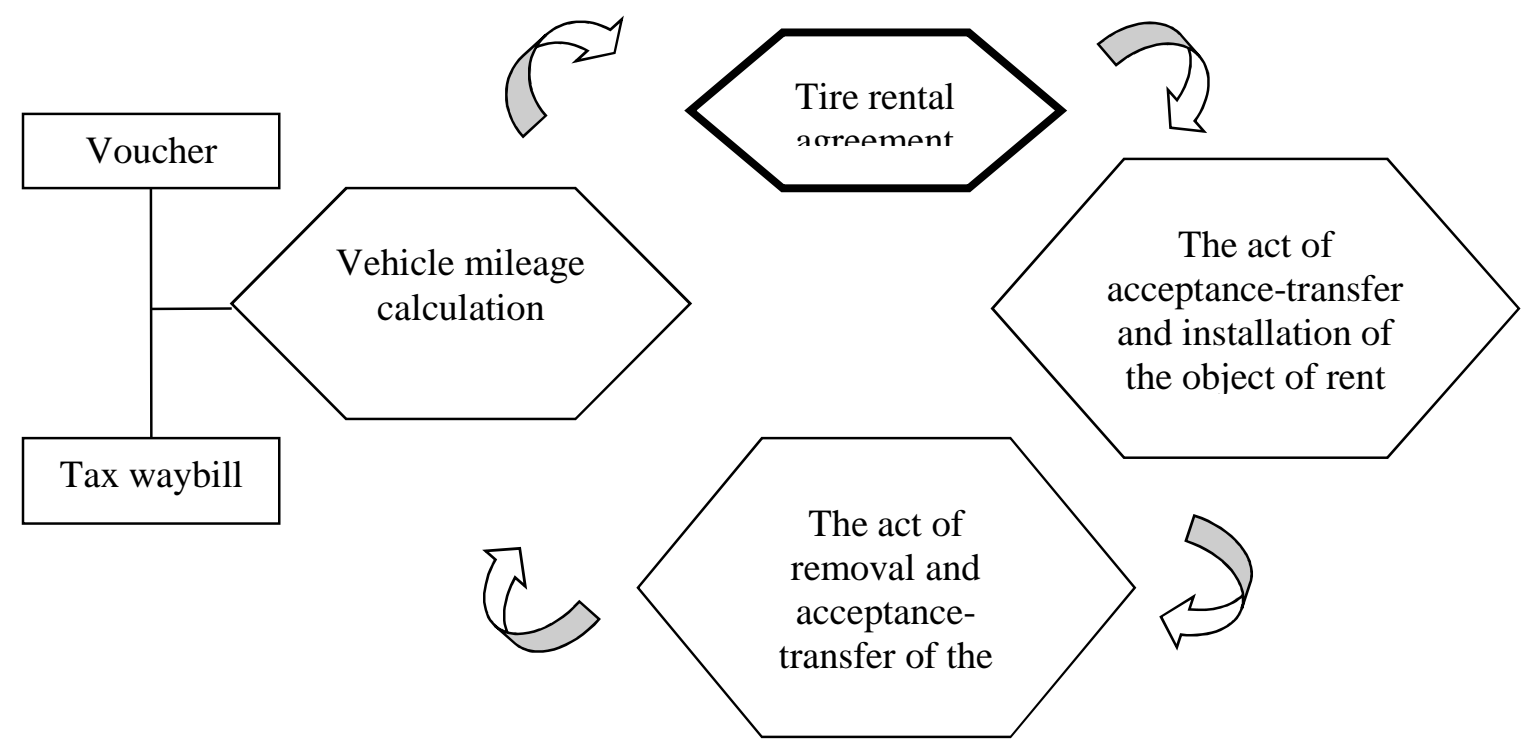

Fig. 8. Recommended document flow for the accounting and control of the rental of pneumatic tires

An algorithm for controlling pneumatic tires and batteries as objects of PPE

Stage 1. Analytical verification of regulatory aspects

(taking into account average tire life and battery performance standards)

Stage 2. Documentary-analytical verification of the receipt of fixed assets (verification of the documents confirming the ownership, compliance of the primary and technical documentation)

Stage 3. Documentary and analytical verification of the use of fixed assets

(check the records in the individual maps of the tire and battery and in the inventory description)

Stage 4. Documentary-analytical verification of the disposal of fixed assets

(check the expediency of disposal; acquaintance with the orders of the governing bodies, acts of acceptance of transfer, liquidation, records in individual cards)

Stage 5. Validation of data on fixed assets recorded in the enterprise's reporting (check for violations of compliance with the principles of preparation of financial statements)

Stage 6. Summarizing the results of the audit

(can be presented in an arbitrary report, in the form of testing compliance with a compiled control program)

Fig. 9. Stages of internal control of the use of pneumatic tires and batteries in the property, plant and equipment of the enterprise 
The recommendations on revision of the accounting policy of the enterprise in the context of the property, plant and equipment proposed earlier and on the introduction of additional forms of documents to ensure the proposed document circulation, in the aggregate, can significantly improve the efficiency of the functioning of the internal control system of the enterprise.

To assess the truth of the analytical and accounting information specified in the documentation and reporting of the enterprise, it is necessary to compare it with the data obtained during internal control. This comparison is proposed to be made in the form shown in Tab. 15.

Systematizing all the improvements proposed in this section, we are developing an internal control program for the use of pneumatic tires and batteries. The plan-program consists of the analysis of tires and batteries, planning, checking of correctness of preparation of primary documents, drafting of correspondence of accounts, depreciation and wear disclosed in Tab. 16 (Appendix L).

Table 15

Form of verification of data on the movement of pneumatic tires and batteries in the enterprise

\begin{tabular}{|c|c|c|c|c|c|c|}
\hline \multirow{2}{*}{ Indicator } & \multicolumn{2}{|c|}{ According to the company } & \multicolumn{2}{|c|}{ According to internal control } & \multicolumn{2}{|c|}{ Deviation } \\
\hline & pieces & UAH & pieces & UAH & pieces & UAH \\
\hline \multicolumn{7}{|c|}{ Pneumatic tires } \\
\hline Revenues & $x$ & $\times$ & $x$ & $x$ & $x$ & $\times$ \\
\hline Repair & $x$ & $x$ & $x$ & $x$ & $x$ & $x$ \\
\hline Seasonal replacement & $\times$ & $\times$ & $\times$ & $\times$ & $\times$ & $\times$ \\
\hline Disposals & $\times$ & $\times$ & $\times$ & $x$ & $x$ & $\times$ \\
\hline Total & $x$ & $x$ & $x$ & $x$ & $x$ & $x$ \\
\hline \multicolumn{7}{|c|}{ Rechargeable batteries } \\
\hline Revenues & $\times$ & $\times$ & $x$ & $\times$ & $x$ & $x$ \\
\hline Repair & $x$ & $x$ & $x$ & $x$ & $x$ & $x$ \\
\hline Disposals & $\times$ & $x$ & $\times$ & $x$ & $x$ & $\times$ \\
\hline Total & & & & & & \\
\hline
\end{tabular}

Methodical approaches to the internal control of spare parts, tires and accumulators as objects of property, plant and equipment, which, unlike existing ones in the enterprise, include: the cycle of document flow of tires and accumulators, with the necessary developed forms of documents, a stepby-step algorithm for conducting internal control of tires and accumulators, an internal control plan was developed with timing, evidence, tasks and control objectives.

\section{Conclusions and prospects of further research}

The work is prepared on the theme "Accounting and control features of the using of spare parts (pneumatic tires, rechargeable batteries) on motor transport enterprises", in which the questions of methodological bases of accounting of spare parts of reuse by motor transport enterprises are considered and recommendations on improvement of their accounting are given both in the conditions of carrying out normal business activity and in the conditions of providing such assets for rent.

In the course of the research, the purpose of the work was achieved and the tasks were solved. The main conclusions are the following:

- The classification of reusable spare parts (including pneumatic tires and batteries) by common practice to current assets of the enterprise is erroneous, because by its nature (the life span exceeds a calendar year, high cost) it is more expedient to identify them as components of property, plant and equipment accounting of trucks. It is also determined that the rental of such spare parts in the regulatory and methodological literature is not foreseen and requires the development of appropriate accounting support.

- Analysis of trends in the development of the Ukrainian transport industry, activities and features of accounting of tires and accumulators of MTE (on the example of PC "AP «AVTOERA»") 
proved the working hypothesis of the research. In connection with this, it was proposed: adjusting the organizational and methodological basis of accounting for pneumatic tires and batteries, developing accounting support for the process of renting tires, improving the internal control system of the company, necessary changes in the accounting policy of the company.

- Developing a system of analytical accounts will improve the quality of accounting and analytical information received and prevent the occurrence of fundamental violations that occurred when accounting for these objects in the inventory. These proposals made it necessary to develop and justify the changes and additions that should be made to the accounting policy of the enterprise. An accounting security was developed for the tire renting process that has not been previously covered in national scientific literature. A number of improvements have been made to the internal control system for pneumatic tires and batteries as a part of property, plant and equipment. The implementation of this proposal implies the introduction of new forms of documents, which is a source of necessary information for internal control.

Based on the results of the study, we can confirm the implementation of the working hypothesis, which is that the adjustment of the methodological basis of accounting for pneumatic tires and batteries will first of all avoid violations of accounting standards and appropriate sanctions, as well as implement the process of renting pneumatic tires with current legislation.

The areas of further research are to improve the development of methodological and conceptual principles for accounting and control of pneumatic tires and batteries in the enterprise.

\section{References}

1. Kirsanova, V. V. \& Kachanova, N. S. (2019) Oblikove zabezpechennia spetsyfichnykh aspektiv ekspluatatsii, spysannia ta orendy shyn [Accounting of specific aspects of operation, listings and rentals of automobile pneumatic tires]. Ekonomika: realii chasu. Naukovyi zhurnal. [Economy: the realities of time. Scientific journal.], 2 (42), 28-36. [in Ukrainian].

2. Selivanova, N. M. \& Kachanova, N. S. (2019) Orhanizatsiino-metodychni aspekty komponentnoho obliku osnovnykh zasobiv v umovakh perekhodu na mizhnarodni standarty finansovoi zvitnosti [Organizational and methodological aspects of the component accounting of fixed assets in the conditions of transition to the international standards of financial reporting]. Ekonomichnyi zhurnal Odeskoho politekhnichnoho universytetu. [Economic Journal of the Odessa Polytechnic University], 4 (10). [in Ukrainian].

3. Balan, A. A. \& Kachanova, N. S. (2019) Porivniannia obliku zapasnykh chastyn za natsionalnymy ta mizhnarodnymy standartamy [Comparison of spare parts accounting by national and international standards]. Oblikovo-analitychne zabezpechennia innovatsiinoi transformatsii ekonomiky Ukrainy: Materialy XIII Vseukrainskoi naukovo-praktychnoi konferentsii (30-31 travnia 2019 roku) [Accounting and analytical support of innovative transformation of Ukrainian economy: Proceedings of the 13th AllUkrainian Scientific and Practical Conference (May 30-31, 2019)]. Odesa: ONPU, 17-19. [in Ukrainian].

4. State Statistics Service of Ukraine (2018) Statystychnyi biuleten "Transport”: za 2016-2018 roky [Statistical bulletin "Transport": for 20162018]. Kyiv: IAA. [in Ukrainian].

5. Normy ekspluatatsiinoho probihu avtomobilnykh shyn: Nakaz Ministerstva transportu Ukrainy No. 420 [Car Tire Operating Norms: Order of the Ministry of Transport of Ukraine No. 420]. (1997). Retrieved from https://zakon.rada.gov.ua/radal show/v0420361-97 [in Ukrainian].

6. Pro zatverdzhennia "Polozhennia pro tekhnichne obsluhovuvannia i remont dorozhnikh transportnykh zasobiv avtomobilnoho transportu": Nakaz. Ministerstva transportu Ukrainy No. 102 [On Approval of the "Regulations on the Maintenance and Repair of Road Motor Vehicles": Order of the Ministry of Transport of Ukraine No. 102]. (1998). Retrieved from https://zakon.rada.gov.ua/laws/ show/z0268-98 [in Ukrainian].

7. Pro zatverdzhennia "Ekspluatatsiinykh norm serednoho resursu pnevmatychnykh shyn kolisnykh transportnykh zasobiv $i$ spetsialnykh mashyn, vykonanykh na kolisnykh shasi”: Nakaz Ministerstva transportu ta zv'iazku Ukrainy No. 488 [On the approval of the "Performance norms of the average life of pneumatic tires of wheeled vehicles and special machines made on wheeled chassis": Order of the Ministry of Transport and Communications of Ukraine No. 488]. (2006). Retrieved from https://zakon.rada.gov.ua/laws/ show/z0712-06 [in Ukrainian].

8. Pro zatverdzhennia "Pravyl tekhnichnoi ekspluatatsii kolis ta pnevmatychnykh shyn kolisnykh transportnykh 


\section{A. Balan, N. Kachanova, E. Topalova}

zasobiv katehorii $L, M, N, O$ ta spetsialnykh mashyn, vykonanykh na yikh shasi”: Nakaz Ministerstva infrastruktury Ukrainy No. 549 [On approval of the "Rules for the Technical Operation of Wheels and Pneumatic Tires of Wheeled Vehicles of Categories L, M, N, O and Special Machines Performed on Their Chassis": Order of the Ministry of Infrastructure of Ukraine No. 549]. (2013). Retrieved from https://zakon.rada.gov.ual laws/show/z1452-13 [in Ukrainian].

9. Pro zatverdzhennia "Pravyl ekspluatuvannia akumuliatornykh svyntsevykh starternykh batarei kolisnykh transportnykh zasobiv $i$ spetsialnykh mashyn, vykonanykh na kolisnykh shasi”: Nakaz. Ministerstva transportu ta zv'iazku Ukrainy No. 795 IOn approval of the "Rules for the operation of lead-acid starter batteries for wheeled vehicles and special machines made on wheeled chassis": Order of the Ministry of Transport and Communications of Ukraine No. 795]. (2008). Retrieved from https://zakon.rada.gov.ua/laws/show/z0689-08 [in Ukrainian].

10. Pro zatverdzhennia "Pravyl nahliadu ta pidtrymannia $v$ robochomu stani starternykh svyntsevo-kyslotnykh akumuliatornykh batarei ND 7214 u 95120-15797”: Nakaz Ministerstva transportu Ukrainy No. 417 [On approval of "Rules for supervision and maintenance of starter lead-acid rechargeable batteries ND 7214 at 95120-157-97": Order of the Ministry of Transport of Ukraine No. 417]. (1997). Retrieved from https://zakon.rada.gov.ua/radal show/v0417361-97 [in Ukrainian].

11. Khimich A. Yu. \& Tsal-Tsalko Yu. S. (2017). Oblik nadkhodzhennia zapasiv vid postachalnykiv na transportnykh pidpryiemstvakh [Accounting for the supply of supplies from suppliers at transport enterprises]. Retrieved from http://ir.znau.edu.ua/ bitstream/123456789/7678/1/OAIKVUSK_2017_42_128-131.PDF [in Ukrainian].

12. Saiko, K. I. \& Zinchenko, O.V. (2017) Metodyka obliku zapasnykh chastyn na avtotransportnykh pidpryiemstvakh [Spare parts accounting at motor transport enterprises]. Retrieved from https://er.knutd. edu.ua/bitstream/123456789/7008/1/20170811_13 2.pdf [in Ukrainian].

13. Fursa, V. P. (2017) Analiz aktualnykh problem obliku operatsii transportu [Analysis of current problems of accounting of transport operations]. Retrieved from http://www.market-infr.od.ua/journals/ 2017/12_2017_ukr/37.pdf [in Ukrainian].

14. Koba, O. V., Turzhans'ka, K. S. \& Sagaidak, N. V. (2016) Oblik vytrat na utrymannia i ekspluatatsiiu avtotransportu na pidpryiemstvi [Cost of maintenance and operation of motor transport at the enterprise]. Retrieved from http://77.121.11.9/ bitstream/PoltNTU/614/3/Коба \%2C \%20Сагайда к \%2C \%20Туржанська \%20\%2B \%20\%20_1_.p df [in Ukrainian].

15. Bilichenko, V. V. \& Antoniuk, O. P. (2016) Obgruntuvannia kryteriiv otsinky efektyvnosti vyboru zapasnykh chastyn, shcho zberihaiutsia na skladi ATP dlia pidtrymky v spravnomu strani yoho rukhomoho skladu [Substantiation of criteria for the evaluation of the efficiency of selection of spare parts stored in the ATP warehouse to maintain its rolling stock in the working country]. Retrieved from http://vtn.ztu.edu.ua/article/view/80421/76197 [in Ukrainian].

16. Akymenko, O., Vertiiko A. \& Minchenko Yu. (2018) Oblikovi aspekty tekhnichnoho obsluhovuvannia ta remontu transportnykh zasobiv [Accounting aspects of vehicle maintenance and repair]. Retrieved from https://ppeu.stu.cn.ua/articles/1554803647061.pdf\# page $=212$ [in Ukrainian].

17. Podatkovyi kodeks Ukrainy [Tax Code of Ukraine] (2008). Retrieved from http://zakon3.rada.gov.ual laws /show/2755-17 [in Ukrainian].

18. Sait internet-mahazynu "Shypshyna". Kataloh tovariv. [The site of the online shop "Shipshina". Product catalog.]. Retrieved from https://shypshyna.com.ua/catalogs/tyres/ [in Ukrainian].

19. Sait internet-mahazynu "Infoshyna". Kataloh tovariv. [The site of the online shop "Infoshina". Product catalog.]. Retrieved from https://infoshina. com.ua/uk/ [in Ukrainian].

20. Zapasy: Polozhennia (standart) bukhhalterskoho obliku 9 [Stocks: Regulation (standard) of accounting 9]. (1999). Nakaz Ministerstva finansiv Ukrainy No. 246 - The order of the Ministry of Finance of Ukraine No.246. Retrieved from https://zakon.rada.gov.ua/laws/show/z0751-99 [in Ukrainian].

21. Osnovni zasoby: Mizhnarodnyi standart bukhhalterskoho obliku 16 [Property, Plant and Equipment: International Accounting Standard 16]. (2012). Retrieved from https://zakon.rada.gov.ual laws/show/929_014 [in Ukrainian].

22. Bazyliuk, A. V. \& Malyshkin, O. I. (2011) Bukhhalterskyi i podatkovyi oblik avtotransportu ta perevezen [Accounting and taxation of motor vehicles and transportation]. Kyiv: Tsentr uchbovoi literatury. [in Ukrainian].

23. Kirsanova, V. V. (2016) Konspekt lektsii z dystsypliny "Bukhhalterskyi oblik u sferakh ekonomichnoi diialnosti” dlia studentiv napriamu pidhotovky 6.030509 "Oblik $i$ audyt" [Lecture notes in the discipline "Accounting in the fields of 
Accounting and control features of the using of spare parts (pneumatic tires, rechargeable batteries)...

economic activity" for students of the field of preparation 6.030509 "Accounting and Auditing"]. Odesa: ONPU, 28p. [in Ukrainian].

24. Osnovni zasoby: Polozhennia (standart) bukhhalterskoho obliku 7 [Fixed assets: Regulation (standard) of accounting 7]. (2000, April 27). Nakaz Ministerstva finansiv Ukrainy No 92 - The order of the Ministry of Finance of Ukraine No92. Retrieved from http://zakon3.rada.gov.ua/laws/ show/z0288-00 [in Ukrainian].

25. Pro zatverdzhennia "Metodychnykh rekomendatsii $z$ bukhhalterskoho obliku osnovnykh zasobiv": Nakaz Ministerstva finansiv Ukrainy No. 561 [On Approval of "Methodological Recommendations for Accounting for Fixed Assets": Order of the Ministry of Finance of Ukraine]. (2003). Retrieved from https://zakon.rada.gov.ua/rada/show/ v0561201-03 [in Ukrainian].

26. Orenda: Polozhennia (standart) bukhhalterskoho obliku 14 [Rent: Regulation (standard) of accounting 14]. (2000). Nakaz Ministerstva finansiv Ukrainy No. 181 - The order of the Ministry of Finance of
Ukraine No. 181. Retrieved from https://zakon.rada. gov.ua/laws/show/z0487-00 [in Ukrainian].

27. Instruktsiia pro zastosuvannia "Planu rakhunkiv bukhhalterskoho obliku aktyviv, kapitalu, zobov'iazan i hospodarskykh operatsii pidpryiemstv $i$ orhanizatsii": Nakaz Ministerstva finansiv Ukrainy No. 291 [Instruction on the application of the Plan of Accounts for Accounting for Assets, Capital, Liabilities and Business Transactions of Enterprises and Organizations: Order of the Ministry of Finance of Ukraine No. 291]. (1999). Retrieved from https://zakon.rada.gov.ua/laws/ show/z0893-99 [in Ukrainian].

28. Pro zatverdzhennia "Polozhennia pro dokumentalne zabezpechennia zapysiv u bukhhalterskomu obliku": Nakaz Ministerstva finansiv Ukrainy No. 88 [On Approval of the "Regulation on Documentary Support of Accounting Entries": Order of the Ministry of Finance of Ukraine No. 88]. (1995). Retrieved from https://zakon.rada.gov.ua/laws/ show/z0168-95 [in Ukrainian]. 